\title{
IMPROVING STUDENTS' LEARNING OUTCOMES THROUGH JIGSAW LEARNING MODEL AT GRADE VI SD NEGERI 066050 MEDAN
}

\author{
Mangara Halomoan Siagian ${ }^{1}$, Ester Julinda Simarmata ${ }^{2}$, Reflina Sinaga ${ }^{3}$, Patri Janson Silaban ${ }^{4}$ \\ 1,2,3,4 Universitas Katolik Santo Thomas, Medan, Indonesia \\ ${ }^{1}$ mangarasiagian99@gmail.com, ${ }^{2}$ julinda@gmail.com, ${ }^{3}$ reflinasinaga@gmail.com, ${ }^{4}$ patri_silaban280388@yahoo.co.id
}

\begin{abstract}
The learning model refers to a learning that encourages students to be active and help each other in mastering the subject. This study aimed to improve students' learning outcomes at grade VI SD Negeri 066050 Medan Denai for the academic year 2020/2021. This research was Classroom Action Research. The results of the study revealed that for the pretest,6 students (23.07\%) reached the target score with an average score of 63.45. In cycle I, there were 11 students (42.30\%) who reached the target, with an average of $67.94 \%$. In cycle II, there were 21 students (84.61\%) who reached the target with an average of $82.56 \%$. The learning implementation was categorized as good. This was seen from the results of observations of teachers' activities in cycle I for $64 \%$ and in cycle II it increased to $82 \%$. Then, the implementation of learning was good. This was seen from the results of students' observation activities in cycle I for $60 \%$ and in cycle II it increased to $88 \%$. Thus, the results of the study showed an increase in students' learning outcomes on the theme of Bumiku, the sub-themes of Earth, the Sun and the Moon of learning 1 and learning 2 at grade VI SD for the academic year 2020/2021. In short, implementing Jigsaw learning model improved students' learning outcomes.
\end{abstract}

Keywords: learning outcomes, jigsaw model

\section{UPAYA MENINGKATKAN HASIL BELAJAR SISWA DENGAN MENGGUNAKAN MODEL PEMBELAJARAN JIGSAW PADA KELAS VI SDN 066050 MEDAN}

\begin{abstract}
ABSTRAK
Model pembelajaran suatu pembelajaran yang mendorong siswa aktif dan saling membantu dalam menguasai materi pelajaran. Penelitian ini bertujuan untuk meningkatkan hasil belajar siswa di kelas VI SD Negeri 066050 Medan Denai Tahun Pembelajaran 2020/2021. Jenis Penelitian ini adalah Penelitian Tindakan Kelas. Berdasarkan hasil penelitian dilihat pada pretes siswa secara individual yaitu 6 orang yang tuntas, secara klasikal yaitu 23.07\% dengan nilai rata-rata 63.45. Pada siklus I secara individual yaitu 11 orang yang tutas, secara klasikal $42.30 \%$ yang tuntas dengan rata-rata 67.94\%. Pada siklus II secara individual yaitu 21 orang yang tuntas, secara klasikal $84.61 \%$ dengan rata-rata $82.56 \%$. Pelaksanaan pembelajaran dengan dikategorikan sudah baik. Hal ini dapat dilihat dari hasil observasi aktivitas guru pada siklus I sebesar $64 \%$ dan pada siklus II meningkat menjadi $82 \%$. Pelaksanaan pembelajaran dengan sudah baik. Hal ini dapat dilihat dari hasil aktivitas observasi siswa pada siklus I sebesar $60 \%$ dan pada siklus II meningkat menjadi $88 \%$. Maka hasil penelitian menunjukkan adanya peningkatan hasil belajar siswa pada tema Bumiku subtema Bumi, Matahari dan Bulan pembelajaran 1 dan pembelajaran 2 dikelas VI SD Tahun Pembelajaran 2020/2021. Hasil penelitian dengan menerapkan Model pembelajaran Jigsaw dapat meningkatkan hasil belajar siswa.
\end{abstract}

Kata Kunci: hasil belajar, model jigsaw

\begin{tabular}{|c|c|c|}
\hline Submitted & Accepted & Published \\
\hline 05 Juni 2021 & 09 Agustus 2021 & 14 September 2021 \\
\hline
\end{tabular}

\begin{tabular}{|l|l|r|}
\hline Citation & $:$ & $\begin{array}{r}\text { Siagian, M.H., Simarmata, E.J., Sinaga, R., \& Silaban, P.J. (2021). Improving Students' Learning Outcomes thorugh } \\
\text { Jigsaw Learning Model at Grade VI SD Negeri 066050 Medan. Jurnal PAJAR (Pendidikan dan Pengajaran), } \\
5(5), 1211-1221 . \text { DOI : http://dx.doi.org/10.33578/pjr.v5i5.8433. }\end{array}$ \\
\hline
\end{tabular}

\section{PENDAHULUAN}

Dalam penyelenggaraannya, pendidikan yang baik adalah pendidikan yang tidak hanya mempersiapkan siswanya untuk suatu jabatan atau profesi tetapi untuk menyelesaikan masalahmasalah yang dihadapinnya dalam kehidupan. Tujuan pendidikan dasar memberikan bekal kemampuan dasar kepada siswa untuk mengembangkan kehidupannya sebagai pribadi, anggota masyarakat, warga Negara dan anggota umat manusia serta mempersiapkan siswa untuk mengikuti pendidikan menengah. Khusus untuk SD tujuan pendidikan adalah memberikan bekal dasar baca tulis hitung,pengetahuan keterampilan dasar yang bermanfaat bagi siswa sesuai dengan 
tingkat perkembangannya, serta mempersiapkan mereka untuk mengikuti pendidikan ketingkat yang lebih tinggi seperti SMP dan SMA. (Mardhatillah Jalaluddin, 2020) Pendidikan adalah proses sadar tujuan. Tujuannya dapat diartikan untuk merumuskan hasil siswa diharapkan setelah pengalaman belajar.

Penilaian hasil belajar secara esensial bertujuan untuk mengukur keberhasilan pembelajaran yang dilakukan oleh guru dan sekaligus mengukur keberhasilan siswa dalam penguasaan itu adalah sesuatu yang sangat penting. Berdasarkan pengamatan awal yang dilakukan terhadap aktivitas pembelajaran Jigsaw pada siswa kelas VI, guru dalam ini belum memanfaatkan penggunaan variasi model pembelajaran. Dalam hal ini model pembelajaran jigsaw belum digunakan guru dalam mingkatkan hasil belajar siswa kelas VI SD Negeri 066050 Medan Denai. Untuk mrngatasi semua permasalah diatas dapat dilakukan dengan memberikan dengan model pembelajaran jigsaw. Model pembelajaran Jigsaw memiliki kelebihan diantaranya dapat mengembangkan Kreativitas, Kemampuan, dan daya pemecahan masalah menurut kehendaknya sendiri.

Prinsipnya model pembelajaran jigsaw dalam membentuk kelompok kecil yang terdiri dari empat sampai enam orang secara heterogen dan siswa bekerja sama saling ketergantungan positif dan bertanggung jawab secara mandiri. Pembelajaran kelompok kecil dengan beraneka ragam karakter dan kemampuan memerlukan pemahaman bersama untuk bekerjasama dan mencapai hasil yang optimal maka masing-masing mempunyai peran untuk mencapai tujuan tersebut. Tujuan dari penelitian ini adalah penggunaan metode pembelajaran Jigsaw untuk meningkatkan hasil belajar siswa.

Berdasarkan hasil observasi yang telah dilakukan oleh peneliti di kelas VI SDN 066050 Medan Denai, ditemukan beberapa masalah dikelas yaitu.(1) rendahnya hasil belajar siswa, (2) dalam proses pembelajaran pendidik kurang memberikan model pembelajaran yang bervariasi dan masih menggunakan model pembelajaran konvensional, (3) kurangnya Penggunaan model pembelajaran Jigsaw yang dilakukan pendidik. Akibat dari kesulitan memahami pembelajaran tematik, maka diperoleh hasil belajar siswa tergolong rendah dan masih dibawah Kriteria Ketuntasan Minimal (KKM) yang ditentukan yaitu yaitu 70 . Hal ini dapat dilihat dari hasil nilai ulangan harian mata pelajaran tema bumiku tahun pembelajaran 2019/2020.

Tabel 1. Data Hasil Nilai Ulangan Harian

\begin{tabular}{|c|c|c|c|c|}
\hline Mata Pelajran & NilaiKKM & Jumlah Siswa & Persentase $\%$ & $\begin{array}{l}\text { Keterangan } \\
\text { Ketuntasan }\end{array}$ \\
\hline \multirow[t]{2}{*}{ IPA } & $70>$ & 7 & $26.92 \%$ & Tuntas \\
\hline & $70<$ & 19 & $73.08 \%$ & Tidak Tuntas \\
\hline \multicolumn{2}{|c|}{ Jumlah } & 26 & $100 \%$ & Sangat tuntas \\
\hline \multirow[t]{2}{*}{ Bahasa Indonesia } & $70>$ & 6 & $23.08 \%$ & Tuntas \\
\hline & $70<$ & $\begin{array}{l}20 \\
26\end{array}$ & $\begin{array}{c}76.92 \% \\
100 \%\end{array}$ & $\begin{array}{l}\text { Tidak tuntas } \\
\text { Sangat tuntas }\end{array}$ \\
\hline
\end{tabular}

Berdasarkan Tabel di atas dapat dilihat bahwa hasil belajar siswa pada semester ganjil tahun pembelajaran 2019/2020 yang menunjukkan bahwa dari 26 siswa, pada mat pelajaran IPA yang tidak tuntas adalah 19 siswa atau $73.08 \%$ dan yang tuntas 7 siswa atau $26.92 \%$ yang mencapai KKM, pada mata pelajaran Bahasa Indonesia yang tidak tuntas 20 siswa atau $76.92 \%$ dan yang tuntas 6 siswa atau $23.08 \%$ yang mencapai KKM. Sesuai permasalahan di atas, maka perlu dilakukan peningkatan hasil belajar siswa dengan menggunakan model pembelajaran jigsaw yang diharapkan dapat meningkatkan hasil belajar siswa pada proses pembelajaran secara efektif dan efesien, sehingga siswa berpikir aktif, kritis dan dapat memecahkan masalah dengan berdiskusi 
bersama kelompok saat proses belajar mengajar. Hal ini didukung hasil penelitian yang dilakukan oleh Wati (2019) tentang upaya meningkatkan hasil belajar IPA di kelas V SD Negeri 11 Ujan Mas membuktikan bahwa penerapan model pembelajaran kooperatif Jigsaw dapat meningkatkan proses pembelajaran, dimana terjadi peningkatan pada siklus I sebesar $62.50 \%$ dengan kategori cukup dan pada siklus II sebesar $89.5 \%$ dengan kategori baik.

\section{KAJIAN TEORETIS Pengertian Belajar}

Didalam lingkungan sekolah maupun Lingkungan tempat sehari-hari penulis dapat menemukan berbagai jenis pengertian belajar, karena kegiatan sehari-hari berawal dari hasil belajar sehingga mampu melaksanakan kegiatan. Menurut Slameto (2013:2) Belajar ialah suatu proses usaha yang dilakukan seseorang untuk memperoleh suatu perubahan tingkah laku yang baru secara keseluruhan, sebagai hasil pengalamannya sendiri dalam interaksi dengan lingkungannya. Hal yang serupa dikatakan oleh Siah (2015:12) mengemukakan bahwa Belajar merupakan kegiatan yang kompleks, Timbulnya kapabilitas disebabkan oleh stimulasi yang berasal dari Lingkungan dan proses kognitif yang dilakukan oleh pelajar. Setelah belajar orang memiliki keterampilan, pengetahuan, sikap, dan nilai. Selanjutnya menurut Simarmata (2016:7) bahwa tujuan utama dengan diselenggarakannya proses belajar adalah demi tercapainya keberhasilan siswa dalam belajar, baik itu suatu pelajaran tertentu maupun pendidikan pada umumnya.

\section{Pengertian Hasil Belajar}

Hasil belajar dalam kelas harus dapat dilaksanakan dalam situasi-situasi di luar sekolah. Dengan kata lain, belajar yang telah dilaksanakan siswa disekolah harus mampu diterapkan secara nyata dalam kehidupan masyarakat. Menurut Hamalik (2017:11) menyatakan bahwa hasil belajar adalah pola-pola perbuatan, nilai-nilai, pengertian-pengertian dan sikap-sikap serta kemampuan siswa. Kemudian menurut Sudjana (2016:15) hasil belajar adalah kemampuankemampuan yang dimiliki oleh siswa setelah menerima pengalaman belajar. Selanjutnya menurut Purwanto (2017:44) bahwa Hasil belajar adalah menunujukkan suatu perolehan akibat dilakukannya suatu aktivitas atau proses yang mengakibatkan berubahnya input secara fungsional. Selanjutnya menurut Purwanto hasil belajar dapat digambarkan sebagai berikut:

Tabel 2. Input Proses Hasil Belajar

\begin{tabular}{lll}
\hline \multicolumn{1}{c}{ Input } & \multicolumn{1}{c}{ Proses } & Hasil \\
\hline Siswa & Proses belajar mengajar & Siswa \\
1.Kognitif & & 1.Kognitif \\
2.Afektif & & 2.Afektif \\
3.Psikomotorik & & 3.Psikomotorik \\
& & \\
Potensi perilaku yang dapat diubah & Usaha mengubah perilaku & $\begin{array}{l}\text { Perilaku yang telah berubah } \\
\text { 1.Efek pengajaran }\end{array}$ \\
& & 2.Efek pengiring \\
\hline
\end{tabular}

\section{Pengertian Model Pembelajaran Jigsaw}

Kata atau istilah model pembelajaran bukanlah sesuatu yang baru bahkan sudah sangat dikenal secara luas, namun dalam pembahasan belajar ini masing-masing para ahli memiliki pemahaman atau defenisi yang berbeda-beda, para pakar dibidang ilmu tentang model pembelajaran juga mengemukakan berbagai variasi batasan tentang model pembelajaran, tentunya didasarkan pemahaman dan aliran ilmu yang mereka anut, berikut akan dikemukakan defenisi model pembelajaran menurut para ahli. Menurut Hariyanto (2019:32) menyatakan bahwa model mengajar dalam membentuk kelompok kecil yang 
terdiri dari empat sampai enam orang secara heterogen dan siswa bekerja sama saling ketergantungan positif dan bertanggung jawab secara mandiri. Pembelajaran kelompok kecil dengan beraneka ragam karakter dan kemampuan memerlukan pemahaman bersama untuk bekerjasama untuk mencapai hasil yang optimal maka masing-masing mempunyai peran untuk mencapai tujuan tersebut. Menurut Istarani (2017:145) mengemukakan maksud dari model pembelajaran adalah guru menetapkan siswa untuk empat sampai enam orang anggota tim bekerja sama dalam tugas akademik dan dibagi menjadi beberapa sub tugas tergantung pada banyak kelompok. Selanjutnya menurut Jihad \& Haris (2012:168) menyatakan bahwa model pembelajaran adalah suatu pembelajaran yang mendorong siswa aktif dan saling membantu dalam menguasai materi pelajaran.

\section{Langkah-langkah Model Pembelajaran Jigsaw}

Model pembelajaran Jigsaw ini digunakan untuk menyampaikan pelajaran yang ditransformasikan langsung oleh guru kepada siswa. Sehingga ada beberapa langkah yang harus diikuti dalam penerapan model ini pada proses belajar mengajar. Menurut Hariyanto (2019:33) mengemukakan langkah-langkah dalam model pembelajaran Jigsaw sebagai berikut:

1. Siswa dikelompokkan kedalam 1 sampai 5 tim.

2. Setiap orang dalam tim diberi bagian materi yang berbeda.

3. Tiap orang dalam tim diberi bagian materi yang ditugaskan.

4. Anggota dari tim yang berbeda yang telah mempelajari bagian yang sama bertemu dalam kelompok baru untuk mendiskusikan hasil kerja mereka.

5. Setelah selesai berdiskusi maka tiap tim mempersentasikan hasil diskusi.

6. Guru memberi evaluai.

7. Penutup

Menurut Rusman (2017:220) dalam penerapan pembelajaran model jigsaw ada beberapa langkah yang harus dilaksanakan, yaitu sebagai berikut:

1. Pembentukan kelompok asal
Setiap kelompok asal terdiri dari 4 sampai 5 orang anggota dengan kemampuan yang heterogen

2. Pembelajaran pada kelompok asal

Setiap anggota dari kelompok asal mempelajari submateri pelajaran yang akan menjadi keahliannya, kemudian masing-masing mengerjakan tugas secara individual.

3. Pembentukan kelompok ahli

Ketua kelompok asal membagi tugas kepada masing-masing anggotanya untuk menjadi ahli dalam satu submateri pelajaran. Kemudian masingmasing ahli submateri yang sama dari kelompok yang berlainan bergabung membentuk kelompok baru yang disebut kelompok ahli.

4. Diskusi kelompok ahli

Anggota kelompok ahli mengerjakan tugas dan saling berdiskusi tentang masalah-masalah yang menjadi tanggung jawabnya.Setiap anggota kelompok ahli belajar materi pelajaran sampai mencapai taraf merasa yakin mampu menyampaikan dan memecahkan persoalan yang menyangkut submateri pelajaran yang menjadi tanggung jawabnya.

5. Diskusi kelompok asal (induk)

Anggota kelompok ahli kembali ke kelompok asal masing-masing kemudian setiap anggota kelompok asal menjelaskan dan menjawab pertanyaan mengenai submateri pelajaran yang menjadi keahliannya kepada anggota kelompok asal yang lain. Ini berlangsung secara bergilir sampai seluruh anggota kelompok asal telah mendapat giliran.

6. Diskusi kelas

Dengan dipandu oleh guru diskusi kelas membicarakan konsep-konsep penting yang menjadi bahan perdebatan dalam diskusi kelompok ahli. Guru berusaha memperbaiki salah konsep pada siswa.

7. Pemberian kuis

Kuis dikerjakan secara individu.Nilai yang diperoleh masing-masing anggota kelompok asal dijumlahkan untuk memperoleh jumlah nilai kelompok.

8. Pemberian penghargaan kelompok

Kepada kelompok yang memperoleh jumlah nilai tertinggi diberikan penghargaan berupa piagam dan bonus nilai. 


\section{METODE PENELITIAN}

Penelitian ini dilaksanakan di SD Negeri 066050 Medan Denai. Waktu penelitian dilaksanakan pada Semester Genap Tahun Ajaran 2020/2021. Subjek penelitian ini adalah semua siswa kelas VI SD Negeri 066050 Medan Denai berjumlah 26 siswa. Objek dalam penelitian ini adalah meningkatkan hasil belajar siswa Pada Tema Bumiku yang diberikan sebagai upaya untuk meningkatkan hasil belajar siswa kelas VI SD Negeri 066050 Medan Denai. Penelitian ini dilaksanakan dalam siklus tindakan, yang mana pada siklus tersebut siklus terdiri dari empat langkah sebagai berikut: (1) perencanaan yaitu merumuskan masalah, menentukan tujuan dan metode penelitian serta membuat rencana tindakan, (2) tindakan yang dilakukan sebagai upaya perubahan yang dilakukan, (3) observasi, dilakukan secara sistematis untuk mengamati hasil atau dampak tindakan terhadap proses belajar mengajar, (4) refleksi, yaitu mengkaji dan mempertimbangkan hasil dampak tindakan yang dilakukan. Teknik pengumpulan data dilakukan melalui tes, observasi dan catatan lapangan. Tes digunakan untuk mengetahui sejauh mana tingkat penguasaan siswa terhadap materi koperasi dan kesejahteraan masyarakat, dan observasi berupa pengamatan terhadap kegiatan siswa dan perubahan yang terjadi pada saat dilakukannya pemberian tindakan dalam pernyataan yang dicatat pada saat pembelajaran berlangsung.

\section{Ketuntasan Belajar Siswa (Individual)}

Setiap siswa dikatakan tuntas belajarnya (ketuntasan individual) jika nilai yang diperoleh siswa telah mencapai nilai KKM 70, karena nilai KKM yang ditetapkan di sekolah yaitu 70 .

Menggunakan rumus persamaan sebagai berikut:

$$
\mathrm{KB}=\frac{T}{T t} \times 100 \%
$$

Keterangan :

$\mathrm{KB}=$ Ketuntasan Belajar

$\mathrm{T}=$ Jumlah skor yang diperoleh siswa

$\mathrm{Tt}=$ Jumlah skor total

Ketuntasan Klasikal
Satu kelas dikatakan tuntas belajarnya (ketuntasan secara klasikal) jika dalam kelas tersebut terdapat $>75 \%$ siswa yang telah tuntas belajarnya dari nilai KKM yang telah ditetapkan disekolah yaitu 70 .

$\mathrm{P}=\frac{\sum \text { siswa yang tuntas belajar }}{\sum \text { siswa }} \times 100$

(Trianto, 2016:241)

Keterangan :

$\mathrm{P}=$ Presentase Ketuntasan Belajar

\section{Rata-rata Hasil Belajar (Mean)}

Dalam mencari peningkatan hasil belajar siswa digunakan rumus rata-rata yaitu :

$\tilde{x}=\frac{\sum x}{N}$

Sudjana (2016:109)

Keterangan :

$\tilde{\mathrm{x}} \quad=$ Rata-rata

$\sum x=$ Jumlah seluruh skor

$\mathrm{N} \quad=$ Banyaknya Objek

Hasil Pembelajaran Aktivitas Guru

Perhitungan nilai akhir setiap observasi ditentukan berdasarkan :

Nilai $\%=\frac{\text { skor total }}{\text { skor } \text { maksimal }} \times 100$

\section{Hasil Pelaksanaan Aktivitas Siswa}

Perhitungan nilai akhir setiap observasi ditentukan berdasarkan :

Nilai Siswa $=\frac{\text { skor total }}{\text { skor maksimal }} \times 100$

\section{Prosedur Penelitian}

Rancangan dalam penelitian ini adalah penelitian tindakan kelas secara garis besar untuk melaksanakan penelitian tindakan kelas. Ada empat tahapan yang harus dilaksanakan menurut Arikunto (2017:42) "Penelitian Tindakan Kelas (PTK) secara garis besar terdapat empat tahapan yang lazim dilalui yaitu : 1) Perencanaan, 2) Pelaksanaan, 3) Pengamatan, 4) Refleksi. Berikut penjelasannya : 
1. Menyusun rancangan tindakan (Planning), dalam tahap ini peneliti menjelaskan tentang tindakan tersebut dilakukan.

2. Pelaksanaan tindakan (Acting), dalam tahap pelaksanaan ini merupakan implementasi atau penerapan dari isi rancangan yaitu mengenakan rancangan tindakan kelas.
3. Pengamatan (Observing), tahap pengamatan yaitu kegiatan pengamatan yang dilakukan oleh pengamat.

4. Refleksi (Reflecting), dalam tahap ini peneliti melakukan evaluasi terhadap apa yang telah dilakukan.

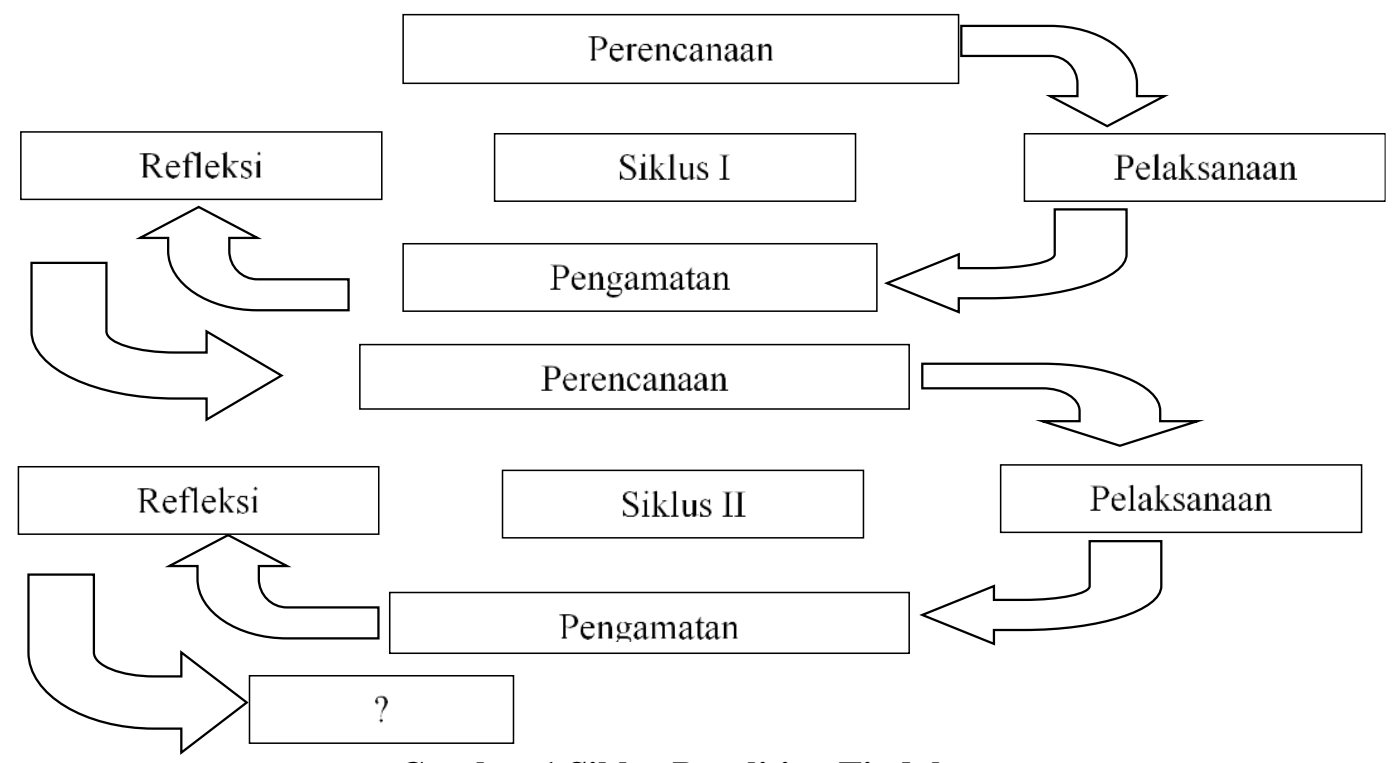

Gambar 1 Siklus Penelitian Tindakan

HASIL DAN PEMBAHASAN

Ketuntasan Hasil Belajar Siswa Secara Individual Pada Pretes

Penelitian dimulai dengan memberikan tes kepada siswa dengan jumlah soal sebanyak 30, untuk mengetahui kemampuan awal siswa dan juga untuk mengetahui kesulitan-kesulitan yang dialami siswa dalam memahami materi pelajaran yang hendak dijelaskan.

Rumus untuk menghitung ketuntasan individu adalah sebagai berikut:

$$
K B=\frac{T}{T t} \times 100 \%
$$

Keterangan :

$\mathrm{KB}=$ Ketuntasan Belajar

$\mathrm{T}=$ Jumlah skor yang diperoleh siswa

$\mathrm{Tt}=$ Jumlah skor total

$$
\mathrm{KB}=\frac{15}{30} \times 100 \%=50
$$

Hasil prates menunjukkan bahwa tingkat ketuntasan belajar kelas VI SDN 066050 Medan Denai.

Ketuntasan hasil belajar secara individual pada tabel 7 dapat dilihat perbandingannya pada diagram di bawah ini. 
Jurnal PAJAR (Pendidikan dan Pengajaran)

Volume 5 Nomor 5 September 2021 | ISSN Cetak : 2580 - 8435| |ISSN Online : 2614 - 1337

DOI : http://dx.doi.org/10.33578/pjr.v5i5.8433

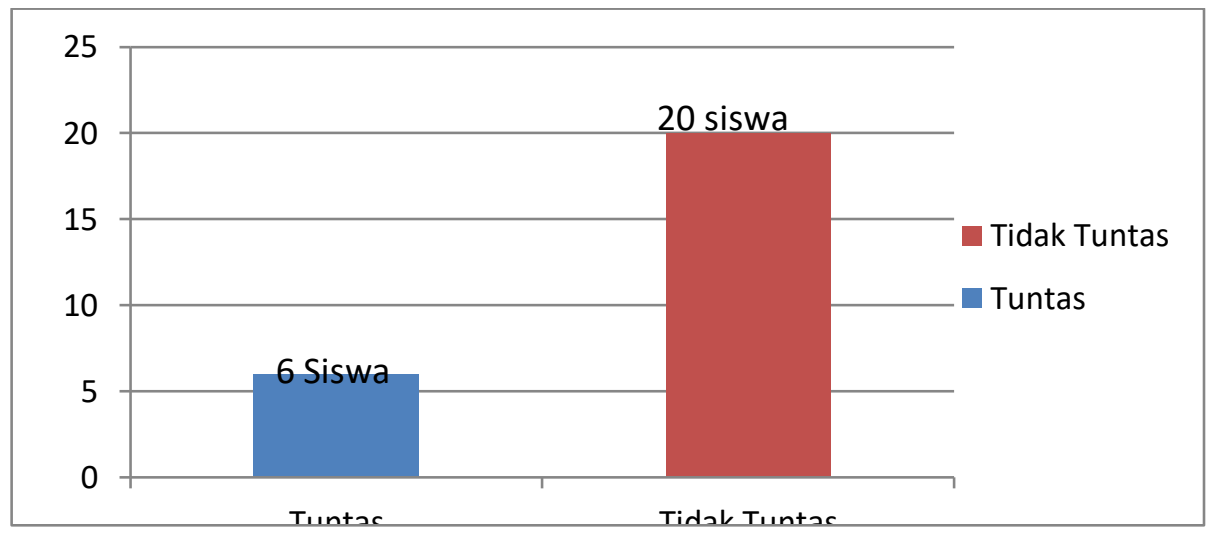

Gambar 2. Diagram Ketuntasan Hasil belajar Pada Prates

Ketuntasan Hasil Belajar Siswa Secara Klasikal Pada Pretes

Setelah diketahui ketuntasan individu, selanjutnya ketuntasan klasikal dirangkum dari hasil belajar siswa yang tuntas dan hasil belajar siswa yang belum tuntas. Siswa yang dapat dikatakan tuntas belajarnya secara klasikal jika di dalam kelas tersebut terdapat $75 \%$ siswa yang tuntas belajarnya. Ketuntasan secara klasikal pada pra siklus ditampilkan pada tabel 4.2 berikut ini :

Tabel 3. Ketuntasan Hasil Belajar Siswa Secara Klasikal Pada Pra siklus

\begin{tabular}{ccc}
\hline Ketuntasan Belajar & Pra siklus \\
\hline & Jumlah Siswa & Persentase \\
Tuntas & 6 orang & $23.07 \%$ \\
Tidak Tuntas & 20 orang & $76.92 \%$ \\
Jumlah & 26 & $100 \%$ \\
\hline
\end{tabular}

Berdasarkan hasil belajar siswa pada pretes, diperoleh tingkat ketuntasan secara klasikal yaitu:

$\mathrm{P}=\frac{\boldsymbol{\Sigma} \text { siswa yang tuntas belajar }}{\boldsymbol{\Sigma} \text { siswa }} \times 100 \%$
Yang tuntas belajar yaitu: $\frac{6}{26} \times 100 \%=23.07 \%$

Yang tidak tuntas yaitu : $\frac{20}{26} \times 100 \%=76.92 \%$

Untuk mengetahui persentase perubahan hasil belajar siswa secara klasikal pada pretes dapat dilihat pada gambar diagram di bawah ini:

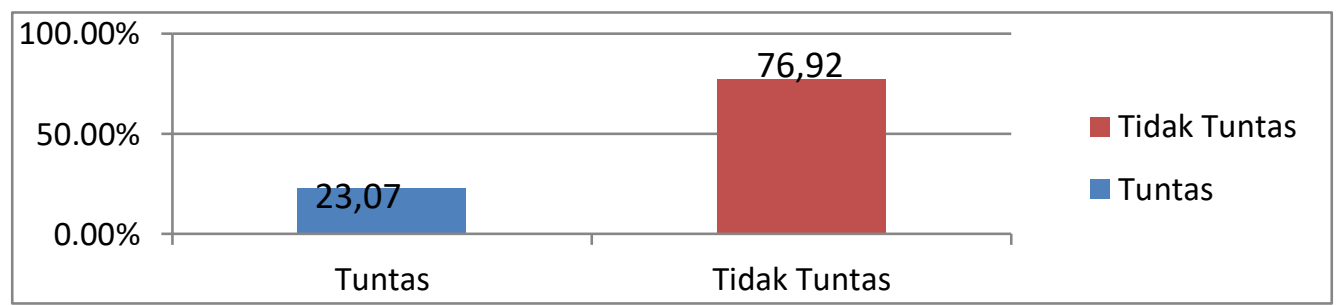

Gambar 3. Diagram Ketuntasan Hasil Belajar Siswa Klasikal Pada Prestes 
Rata-rata Hasil Belajar Siswa Pada Pretes

Dari hasil ketuntasan belajar individu dan klasikal maka dapat diperoleh nilai rata-rata siswa. $x=\frac{\sum X}{\sum N}=\frac{1649,86}{26}=63,45$ (cukup)

Ketuntasan Hasil Belajar Siswa Secara Individu Pada Postes Siklus I

Pada akhir pembelajaran, setelah guru melaksanakan langkah-langkah pembelajaran sesuai dengan model pembelajaran Jigsaw, guru kembali memberikan tes dengan jumlah soal sebanyak 15, dimana yang bertujuan untuk mengetahui tingkat keberhasilan dari tindakan yang telah diberikan. Dari hasil tes yang telah diperoleh dalam pelaksanaan penelitian siklus I maka diperoleh hasil belajar siswa secara individual dengan menggunakan rumus sebagai berikut:

$$
K B=\frac{T}{T t} \times 100
$$

Keterangan :

$\mathrm{KB}=$ Ketuntasan Belajar

$\mathrm{T}=$ Jumlah skor yang diperoleh siswa

$\mathrm{Tt}=$ Jumlah skor total

$\mathrm{KB}=\frac{11}{15} \times 100=73,33$

Ketuntasan secara individual pada tabel dapat dilihat perbandingannya pada diagram di bawah ini:

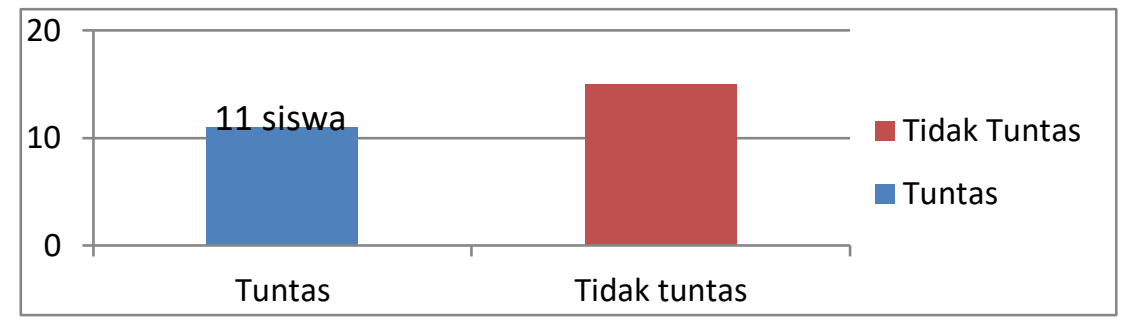

\section{Gambar 4. Diagram Ketuntasan Hasil Belajar Secara Individual Pada Siklus I}

\section{Ketuntasan Hasil Belajar Siswa Secara Klasikal Pada Siklus I}

Setelah diketahui ketuntasan individu, selanjutnya ketuntasan hasil belajar secara klasikal yang dilihat dari hasil belajar siswa dalam satu kelas. Siswa yang dikatakan tuntas hasil belajarnya secara klasikal jika di dalam kelas tersebut terdapat 75\% siswa yang mendapat nilai tuntas dan mencapai nilai dibawah Kriteria Ketuntasan Minimal (KKM) yang telah ditetapkan. Ketuntasan hasil belajar siswa secara klasikal dapat dilihat sebagai berikut :

Tabel 5 Ketuntasan Hasil Belajar Siswa Secara Klasikal Pada Postes Siklus I

\begin{tabular}{lcc}
\hline \multicolumn{1}{c}{ Keterangan } & \multicolumn{2}{c}{ Siklus I } \\
\cline { 2 - 3 } & Jumlah Siswa & Persentase \\
\hline Jumlah siswa yang tuntas & 11 & $42.30 \%$ \\
Jumlah siswa yang tidak tuntas & 15 & $57.69 \%$ \\
Jumlah siswa & 26 & $100 \%$ \\
\hline
\end{tabular}

Untuk menghitung ketuntasan secara klasikal

इsiswa

dapat dihitung dengan rumus berikut

$\mathrm{P}=\boldsymbol{\Sigma}$ siswa yang tuntas belajar $\mathrm{x} 100 \%$

Yang tuntas belajar yaitu: $\frac{11}{26} \times 100 \%=42.30 \%$ 
Yang tidak tuntas yaitu : $\frac{15}{26} \times 100 \%=57.69 \%$

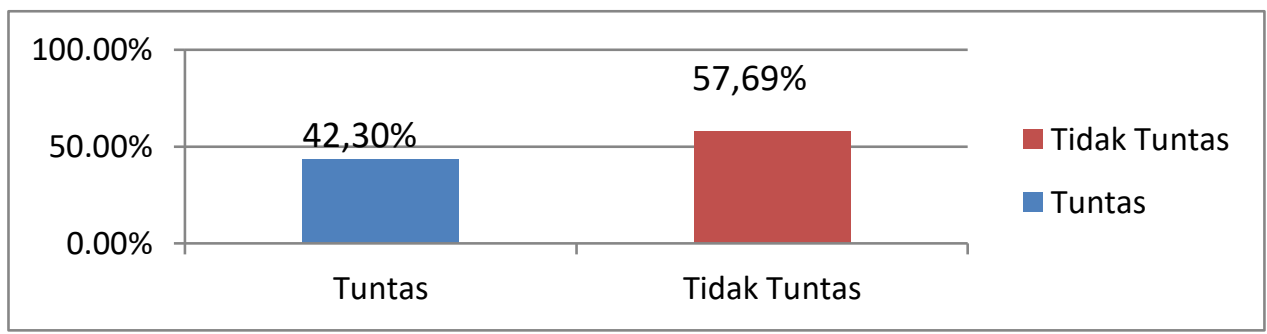

Gambar 5 Ketuntasan Hasil Belajar Siswa Secara Klasikal Pada Siklus I

\section{Rata-rata Hasil Belajar Siswa Pada Siklus I}

Dari hasil ketuntasan belajar individu dan klasikal maka dapat diperoleh nilai rata-rata belajar siswa yang dihitung dengan menggunakan rumus berikut:

$$
\begin{aligned}
& x=\frac{\sum x}{\sum N} \\
& x=\frac{1766,59}{26} \\
& x=67,94 \text { (Baik) }
\end{aligned}
$$

\section{Ketuntasan Hasil Belajar Siswa Secara Individu Siklus II}

Pada akhir pembelajaran, setelah semua materi pembelajaran diajarkan guru kembali memberikan tes yang bertujuan untuk mengetahui tingkat keberhasilan atas tindakan yang diberikan. Dari hasil tes yang diperoleh peneliti pada penelitian tindakan kelas, diperoleh ketuntasan belajar siswa secara individual dengan rumus sebagai berikut:

$$
K B=\overline{T t}_{\mathrm{x}} 100
$$

Keterangan :

$\mathrm{KB}=$ Ketuntasan Belajar

$\mathrm{T}=$ Jumlah skor yang diperoleh siswa

$\mathrm{Tt}=$ Jumlah skor total

$\mathrm{KB}=\frac{12}{15} \times 100 \%=80$

Ketuntasan secara individual dilihat perbandingannya pada diagram berikut ini.

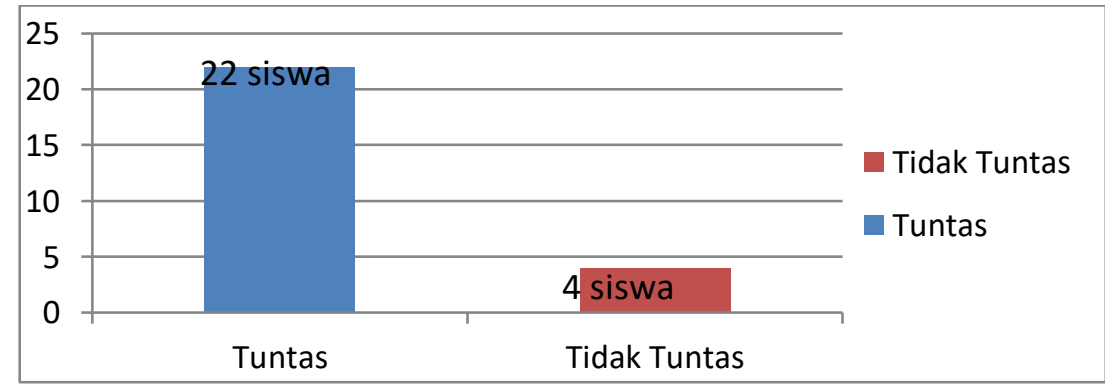

Gambar 6 Ketuntasan Hasil Belajar Siswa Secara Individual Pada Siklus II

\section{Ketuntasan Hasil Belajar Siswa Secara Klasikal Pada Siklus II}

Berdasarkan hasil belajar yang diperoleh peneliti pada tindakan siklus II hasil belajar siswa secara klasikal mengalami peningkatan terhadap hasil belajar siswa secara klasikal yaitu $84 \%$. Untuk lebih jelasnya dapat dilihat pada tabel di bawah ini. 
Tabel 6. Ketuntasan Hasil Belajar Siswa Secara Klasikal Pada Postes Siklus II

\begin{tabular}{ccc}
\hline Keterangan & \multicolumn{2}{c}{ Siklus II } \\
\cline { 2 - 3 } & Jumlah Siswa & Persentase \\
\hline Jumlah siswa yang tuntas & 22 & $84.61 \%$ \\
Jumlah siswa yang tidak tuntas & 4 & $15.39 \%$ \\
Jumlah siswa & 26 & $100 \%$ \\
\hline
\end{tabular}

Untuk menghitung ketuntasan secara klasikal dapat dihitung dengan rumus berikut $\mathrm{P}=\boldsymbol{\Sigma}$ siswa yang tuntas belajar $\mathrm{x} 100 \%$

$$
\boldsymbol{\Sigma} \text { siswa }
$$

Yang tuntas belajar yaitu: $\frac{22}{26} \times 100 \%=84.61 \%$
Yang tidak tuntas yaitu : $\frac{4}{26} \times 100 \%=15.39 \%$

Ketuntasan hasil belajar secara klasikal pada grafik dapat dilihat perbandingannya pada diagram berikut ini.

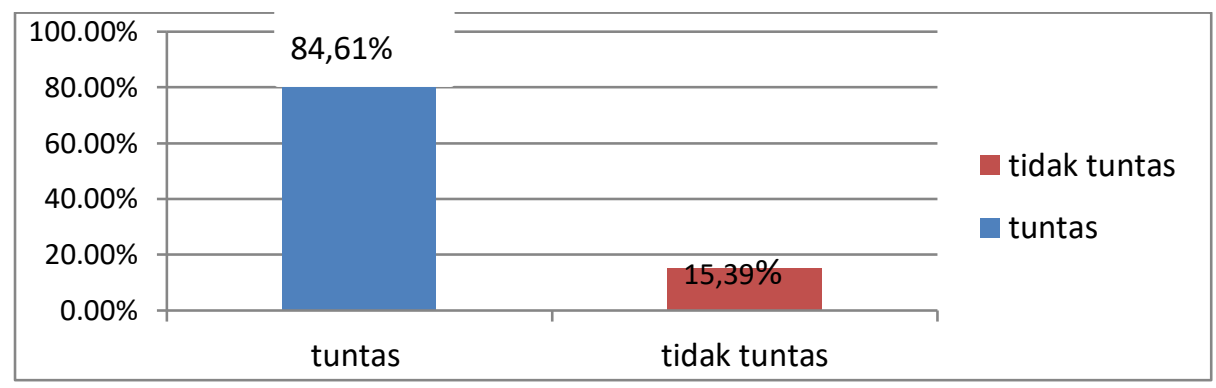

Gambar 7. Ketuntasan Hasil Belajar Secara Klasikal Pada Siklus II

\section{Rata-rata Hasil Belajar Siswa Pada Siklus II}

Dari hasil ketuntasan belajar individu dan klasikal maka dapat diperoleh nilai rata-rata belajar siswa yang dihitung dengan menggunakan rumus berikut:

$$
\begin{aligned}
& x=\frac{\sum x}{\sum N} \\
& x=\frac{2146,56}{26} \\
& x=82,56 \text { (Baik) }
\end{aligned}
$$

\section{SIMPULAN DAN REKOMENDASI}

Berdasarkan hasil penelitian yan dilakukan oleh peneliti dengan Model pembelajaran Jigsaw bahwa dengan menerapkan Model pembelajaran Jigsaw pada tema bumiku, dapat meningkatkan hasil belajar siswa dan sudah memenuhi kriteria ketuntasan minimal (KKM) yang telah ditetapkan oleh sekolah yaitu 70 . Hal ini dapat dilihat dari persentase ketuntasan belajar individu , klasikal, dan nilai rata-rata siswa yaitu ; pada pretes siswa secara individual yaitu 6 orang yang tuntas, secara klasikal yaitu $23.07 \%$ dengan nilai rata-rata 63.45. Pada siklus I secara individual yaitu 11 orang yang tutas, secara klasikal $42.30 \%$ yang tuntas dengan rata-rata $67.94 \%$. Pada siklus II secara individual yaitu 21 orang yang tuntas, secara klasikal $84.61 \%$ dengan rata-rata $82.56 \%$. Pelaksanaan pembelajaran dengan Model pembelajaran Jigsaw pada tema bumiku di kelas VI SDN 066050 Medan Denai Tahun Pembelajaran 2020/2021 dikategorikan sudah baik. Hal ini dapat dilihat dari hasil observasi aktivitas guru pada siklus I sebesar $64 \%$ dan pada siklus II meningkat menjadi $82 \%$. Pelaksanaan pembelajaran dengan Model pembelajaran Jigsaw di kelas VI SDN 066050 Medan Denai pada tema bumiku dikategorikan sudah baik. Hal ini dapat dilihat dari hasil aktivitas observasi siswa pada siklus I sebesar $60 \%$ dan pada siklus II meningkat menjadi $88 \%$. 


\section{DAFTAR PUSTAKA}

Arikunto. (2017). Penelitian tindakan kelas. Jakarta: PT. Bumi Aksara.

Hamalik. (2017). Proses Belajar Mengajar. Jakarta: PT. Bumi Aksara.

Hariyanto, A. (2019). Teams Games Tournament Dan Jigsaw Melalui Pendekatan Saintifik. Yogyakarta: Grup CV Budi Utama.

Istarani. (2017). Inovatif, 58 Model Pembelajaran. Medan: Media Persada.

Istirani, P. (2017). Ensiklopedia Pendidikan. Medan: CV ISCOM Medan.

Jihad. (2012). Evaluasi Pembelajaran. Yogyakarta: Multi presindo.

Khairani. (2017). Psikologi Belajar. Yogyakarta: Aswaja Presindo.

Mardhatillah, J. P. J. (2020). The effect of emotional intelligence on the results of learning mathematics in students elementary school. Advances in Mathematics: Scientific Journal, vol: 9 | issue : 12 .

Ngalimun. (2017). Strategi dan model pembelajaran. Yogyakarta: Aswaja Presindo.

Purwanto. (2017). Evaluasi Hasil Belajar. Yogyakarta: Pustaka Belajar.

Rusman. (2017). Model-model Pembelajaran Mengembangkan Propesionalisme Guru. Jakarta: PT. Raja Grafindo Persada.

Shoimin. (2016). 68 Model Pembelajaran Model Inovatif Dalam Kurikulum 2013. Yogyakarta: Ruzz Media.

Siah, M. (2015). Psikologi belajar. Bandung: PT. Raja Grafindo Persada.

Siburian. (2013). Evaluasi Belajar (1st ed.; M. SURIP, ed.). Jakarta: GROGOL PETAMBURAN.

Simarmata, E. J. (2011). Penerapan Model Pembelajaran Snowball Throwing Untuk Meningkatkan Hasil Belajar Siswa Kelas IV SD Kartika I-1 Ester. 1-6.

Sinaga, R. (2015). Penggunaan model pembelajaran time token dalam meningkatkan keterampilan berbicara pada mata pelajaran bahasa indonesia siswa kelas V SDN 028229 Payaroba Kota Binjai. PGSD FIP UNIMED, 4.
Slameto. (2013). Belajar dan Faktor-faktor Yang Mempengaruhi (6th ed.). Jakarta: PT Rineka Cipta.

Sudjana, N. (2016). Penilaian Hasil Proses Belajar Mengajar. Bandung: PT Remaja Rosdakarya.

Sugiyono. (2018). Metode penelitian kuantitatif, kualitatif. Bandung: Alpabeta.

Susanto, A. (2017). Teori belajar Dan Pembelajaran Di Sekolah Dasar. Jakarta: Kencana.

Tampubolon. (2014). Penelitian Tindakan Kelas. Jakarta: PT Erlangga.

Trianto. (2016). Mendesain Model Pembelajran Inovatif-progresif.

Wati, N. H. (2019). "Penerapan Model Pembelajaran Kooperatif Tipe Jigsaw untuk Meningkatkan Hasil Belajar IPA di Kelas V SD Negeri 11 Ujan Mas". Jurnal PGSD, 12(1), 41-48 